\title{
Socioeconomic Impact of Climate Change in Rural Areas of Greece Using a Multicriteria Decision-Making Model
}

\author{
Ioannis Georgilas ${ }^{1}$, Christina Moulogianni ${ }^{1}$, Thomas Bournaris ${ }^{1, *(\mathbb{D}, \text { George Vlontzos }}{ }^{2}$ and Basil Manos $^{1}(\mathbb{D}$ \\ 1 Department of Agricultural Economics, Aristotle University of Thessaloniki, 54124 Thessaloniki, Greece; \\ igeorgil@agro.auth.gr (I.G.); kristin@agro.auth.gr (C.M.); manosb@agro.auth.gr (B.M.) \\ 2 Department of Agriculture, Crop Production and Rural Development, University of Thessaly, \\ 38446 Volos, Greece; gvlontzos@agr.uth.gr \\ * Correspondence: tbournar@agro.auth.gr; Tel.: +30-2310998423
}

\section{check for} updates

Citation: Georgilas, I.; Moulogianni, C.; Bournaris, T.; Vlontzos, G.; Manos, B. Socioeconomic Impact of Climate Change in Rural Areas of Greece Using a Multicriteria

Decision-Making Model. Agronomy 2021, 11, 1779. https://doi.org/ 10.3390/agronomy11091779

Academic Editors: Alfonso Exposito, Julio Berbel and Javier

Martínez Dalmau

Received: 31 July 2021

Accepted: 3 September 2021

Published: 4 September 2021

Publisher's Note: MDPI stays neutral with regard to jurisdictional claims in published maps and institutional affiliations.

Copyright: (c) 2021 by the authors. Licensee MDPI, Basel, Switzerland. This article is an open access article distributed under the terms and conditions of the Creative Commons Attribution (CC BY) license (https:// creativecommons.org/licenses/by/ $4.0 /)$.

\begin{abstract}
Agriculture is the main and, in some cases, the only, source of income and employment in rural areas. The change in the conditions under which agriculture is practiced has various effects on the agricultural economy but also on the social structure of rural areas. Climate change has multiple effects on agricultural production, necessitating the reorganization of agricultural production in some cases. These effects of climate change will also impact the economic and social aspects of farms in rural areas. This paper attempts to identify these effects by measuring the socioeconomic impacts of climate change in the region of Central Macedonia in Greece. For this reason, a multicriteria model was developed to simulate these impacts by estimating a set of seven social and economic indicators. The model was implemented to the average farm which was estimated from the main cultivations of the region. A scenario analysis was also used in combination with the multicriteria model. The multicriteria model suggests modifications are needed in the average farm crop plan of the region as a result of the climate change impact. The scenarios results show that climate change will negatively affect all the social and economic indicators and will continue to affect them over the years. These results can be used by policymakers to understand the economic and social impacts of climate change in the region to plan their future policies.
\end{abstract}

Keywords: climate change; social impact; economic impact; multicriteria analysis

\section{Introduction}

Climate change is a reality that is perceived in many aspects of human activity. The impacts of climate change are multifaceted, affecting the environment primarily, and all human activities related to it. Agriculture is one of the most affected sectors, as the interactions between the environment and agriculture are multifaceted and complex. The exact, positive or negative, effect of agriculture on the environment depends on the intensification of agricultural production and the structure of crops. These are the management of soil resources [1], the protection of ecosystem functions [2], and the formation of microclimates. At the same time, the main effects of agriculture on the environment are related to water resources, soil, and the atmosphere [1,3].

Thus, in the light of the globalization of markets and the implementation of environmentally friendly agricultural policy measures, the aim is to mitigate the effects of climate change and adapt agriculture to this new environment [4-7]. Without this necessary adjustment, the competitiveness of production systems will be lost, and it will not be possible to meet global demand. This need for adjustment has been seen as synonymous with increasing or stabilizing productivity [8], but lately different views have emerged, focusing on differentiating production directions and scale of production [9].

The change in the conditions in which agriculture is practiced affects, in various ways, not only the agricultural economy but also the social structure of rural areas, if one considers that agriculture is the main, in some cases the only, source of income and employment in 
rural areas. In the context of a globalized rural economy, Kanellopoulos et al. [10] found that climate change could benefit entrepreneurs operating at the business level, seeking to maximize profits, but smallholders and family farms would be the losers in this process. In fact, Parry et al. [11] had already found that in developed countries, climate change will continue to improve yields, achieving food security worldwide. In contrast, Jones and Thornton [12] predicted an overall 10\% reduction in maize production in Latin America, noting at the same time very large differences in the magnitude of this reduction between regions, which also delimit the magnitude of the socioeconomic impact of climate change. In addition, the potential reduction of nitrogen fertilizer use will increase the role of low-input crops and agricultural practices [13].

Thus, at the socioeconomic level, it is reasonable to expect sharpening of the contradictions in the rural area, however their general prediction is not possible, due to the local peculiarities and the endogenous characteristics of the productive systems worldwide. An example of developing alternative scenarios for agriculture in the light of climate change is the work of Abildtrup et al. [14] utilizing the "analytic hierarchy process" methodology. In Australia, there is relevant research, for example the work of Nelson et al. [15], who seek to develop a model for predicting the impact of climate change by correlating each scenario with specific socioeconomic impacts.

This paper aimed to calculate the social and economic impacts of climate change in rural areas of Greece. For this reason, a multicriteria model was developed, focusing on the reorganization of the production plan of the region of Central Macedonia in Greece. Furthermore, a scenario analysis was implemented. These scenarios measure the impact of climate change in seven indicators (five economic and two social) that are considered crucial for the farm owners. These indicators were selected following the limitations presented in previous studies in the area, following the balance between the data availability and the needs of farmers and policymakers.

In the following section, the combination of multicriteria methodology with the scenario analysis is presented. The results of the model application and the discussion of the scenario analysis results are given in Section 3. Finally, the last section offers the conclusions and suggestion of the research.

\section{Materials and Methods}

In recent years, several researchers have assessed the impacts of climate change in different countries. At the same time, the resilience and adaptability of small rural societies to these new conditions have been studied [16-21]. Lal et al. [22] found that the effects of climate change are generally more pronounced in rural areas than in urban areas of the United States. In addition, Cierco Gomes [23], in her study for the Western Balkans, argues that climate change will affect mainly the rural areas, and they are expected to experience economic downturn and social consequences. In addition, Salvia et al. studied how land management in Mediterranean Europe impacts the land degradation, evidencing the intimate relationship between agriculture and sociodemographic factors of rural areas [24]. In Greece, specific effects of climate change on agricultural productivity have been recorded [25], noting the need to restructure crops and introduce new production standards.

According to the OECD [26], "Greece's unique geographical characteristics, shape the distribution and access of people and resources across the regions". These characteristics result in populations living in low-density rural areas with less access to cities than in other OECD countries. The region of Central Macedonia was selected due to the importance of the rural areas of the region among the 13 Greek regions. The region is the largest, and second in terms of population in Greece. With regard to the regions' social and economic profile, in 2019 , the region employed $16.5 \%$ of the country's workforce, while $13 \%$ of them were employed in the primary sector [27]. In addition, the gross domestic product (GDP) of the region accounted for 13.8\% (EUR 25.56 B) of the national GDP [27].

As mentioned above, the methodology used was scenario analysis based on multicriteria decision-making to measure the socioeconomic impacts of climate change in rural areas. 
According to Recchia et al. [28], multicriteria analysis is useful to detect all the possible solutions and identify the optimum ones to minimize the costs and the environmental issues related to climate change. Sumpsi et al. [29,30] and Amador et al. [31] propose weighted goal programming as a methodology of decision-making problems, which is based on multicriteria techniques. This methodology has been extended and has been successfully implemented in different studies where conflicting goals can affect farmers decisions [32-38]. The model is a multicriteria decision-making (MCDM) model and was developed due to the different and conflicting criteria which farmers consider when they plan their production. In addition, the variables of the model are related to different environmental, economic, and social attributes. Finally, the model, in comparison with other methodologies or techniques, can achieve the optimum allocation for the production factors (land, labor, capital), while it simultaneously optimizes several conflicting criteria, such as the maximization of gross margin, the minimization of labor use, the minimization of fertilizers use, etc. Briefly, the methodology estimates a utility function (UF) in order to simulate farmers' decision-making processes, broadening their main goal which is profit maximization [39]. The UF is then used to calculate the optimum values for the main objectives, in our case gross margin (max), fertilizers use (min), and labor use (min). The methodology is implemented in the average farm of the region. The average farm has a set of variables, $\mathrm{Xi}$ (crops), which represent the cultivated area of the farm. These are the decision variables, and the total cultivation area of the average farm for all crops (Xi) should be equal to 100 ha. This assumption is used to obtain the results of the model (decision variables, $\mathrm{Xi}$ ) in percentages.

In brief, the methodology can be summarized in the following steps. The first step is the definition of a tentative set of objectives $f_{1}(\mathrm{X}) \ldots f_{i}(\mathrm{X}) \ldots f_{n}(\mathrm{X})$ which are assumed to represent the real objectives of the farmers [31]. Once these objectives have been defined, the next step is the calculation of the pay-off matrix. The pay-off matrix data are calculated with an optimization of one objective in each different row. When the payoff matrix has been obtained, the following system of $q$ equations is solved:

$$
\sum_{i=1}^{q} w_{j} f_{i j}=f_{i}, i=1,2, \ldots q
$$

and

$$
\sum_{j=1}^{q} w_{j}=1
$$

where:

$w_{\mathrm{j}}$ are the weights for each objective that represent the real behavior of the farmer.

$f_{i j}$ are the elements of pay-off matrix.

$f_{i}$ is the value achieved for the $i_{\text {th }}$ objective according to the real crop plan.

The result of the above system does not give a set of weights. It is necessary to search for the optimum solution by minimizing the sum of deviational variables that find the closest set of weights. The next step is to formulate a weighted goal programming model with percentage deviational variables [40]. The final solution for the weights is obtained by solving the next linear programming (LP) model:

$$
\begin{gathered}
\min \sum_{i=1}^{q} \frac{n_{i}+p_{i}}{f_{i}} \\
\sum_{j=1}^{q} w_{j} f_{i j}+n_{i}-p_{i}=f_{i}, i=1,2, \ldots q
\end{gathered}
$$

and

$$
\sum_{j=1}^{q} w_{j}=1
$$


where:

$p_{i}$ is the positive deviational variable (i.e., the measurement of the overachievement of the $i_{\text {th }}$ objective respect to a given target).

$n_{i}$ is a negative deviational variable that measures the difference between real value and model solution for the $i_{t h}$ objective.

In the next sections, the proposed objectives, constraints, and scenarios to measure the socioeconomic impact of climate change in rural areas are presented.

\subsection{Objectives}

The multicriteria model optimizes, at the same time, gross margin (max), fertilizers use ( $\mathrm{min}$ ), and labor use (min). These three goals were selected as the farmers' objectives to achieve better economic (gross margin), environmental (fertilizers), and social (labor) results.

\subsection{Constraints}

This multicriteria decision-making model was developed aiming at optimizing the farm plan of the region of Central Macedonia in Greece, considering the available resources. A set of constraints was developed regarding land use (ha), labor use (hours), capital (EUR), irrigation of crops (ha), common agricultural policy (CAP), and other market related parameters, as well as rotational and agronomic considerations of crops in the selected area.

- Land use: The sum of total available land for all crops (Xi) must add up to 100. This constraint is only introduced to obtain the outcome of the model as percentages.

- Labor use: The sum of required working hours (RWHi) for each crop (Xi) must be less than or equal to the total available working hours (TWH).

- Capital: The sum of the required capital (RCi) for each crop (Xi) must be less than or equal to the total available capital (TC).

- Irrigation: The total land of irrigated crops must be less than or equal to the total irrigated land of the region. Irrigated crops in this study were cotton, alfalfa, sunflower, maize, and rice. Non irrigated crops were soft wheat, hard wheat, and barley.

- CAP rights: The sum of production rights (PRi) for crops (Xi), according to CAP regulations, should be less than or equal to the total production rights of the area (TPR).

- Other constraints: Market and agronomics considerations, such as rotation (they were defined according to market limitations and are based on the maximum historical cultivation during the planning period).

\subsection{Scenarios}

The model was also used for the simulation of climate change scenarios. These scenarios were developed by combining different scenario developing approaches. They are based on changes of different environmental parameters such as water and fertilizers use. At first, the representative concentration pathways (RCPs) [41] and the shared socioeconomic pathways [42], and their predictions and suggestions were analyzed. In addition, the European socioeconomic scenarios for climate change proposed by Kok et al. [43] and the approach based on shared socioeconomic pathways of Kriegler et al. [44] were taken into account. Finally, the European Environment Agency (EEA) provides a dataset [45] for a large number of indicators that affect climate change in European Union countries, and specifically the agricultural sector. The study led to a large number of different scenario combinations with too many different parameters that in our case were not affected by the farmers' decisions. Therefore, a focus on a set of criteria that affect farmer decisions were agreed upon. For this reason, a survey among farmers and stakeholders (54 respondents in total) was conducted, with a questionnaire regarding the most important climate change indicators. The responses of this survey were considered, and fertilizers and water use were the two main parameters, from the EEA indicators, that were selected in this study. In addition, the time frame was selected by farmers and stakeholders, analyzing their responses to the survey. 
The final decision was to adapt three local scenarios. According to Schermer et al. [46], "locally adapted scenarios illustrate the future land-use changes as a result of both climate change and different socioeconomic developments". The three scenarios derived from this process were the baseline scenario for the year 2018, scenario I for the year 2025, and scenario II for the year 2030. The data for the predictions on fertilizers and water use for Greece were derived from the European Environment Agency (EEA) [45]. The EEA presents data for trends and projections of energy, emissions of greenhouse gases, and some other indicators up to 2030, and cover EU25 members countries. These data were last modified in 2017 and have been compiled by the European Topic Centre (ETC) on Air and Climate Change of EEA. For Greece, the EEA predicts that from 2020 to 2030, the fertilizers use will decrease by $-0.6 \%$ per year and the annual change for water use will be $-0.7 \%$ (Table 1).

Table 1. Selected scenarios.

\begin{tabular}{ccc}
\hline Scenarios & Fertilizers Use & Water Use \\
\hline Baseline (2018) & No change & No change \\
Scenario I (2025) & $-4.20 \%$ & $-4.90 \%$ \\
Scenario II (2030) & $-7.20 \%$ & $-8.40 \%$ \\
\hline
\end{tabular}

These scenarios were used to measure the proposed crop plans and their participation in the agricultural land use and the climate change impact on specific economic and social indicators for the years of 2018, 2025, and 2030.

\subsection{Socioeconomic Indicators}

Another issue was the selection of the socioeconomic indicators. The selection of the appropriate indicators requires data availability and the use of data that can be easily obtained [47]. We used a set of economic and social indicators proposed by the Hellenic Statistical Authority (HSA). The HSA proposes many indicators to describe economic and social phenomena. We used the following economic and social indicators, which reflect the balance between the ideal indicators and the limitations of data availability in Greece. The economic indicators are farm income (EUR) (divided into family farm income (EUR) and gross added value (E)), gross revenue (EUR), variable cost (EUR/ha), gross margin (EUR/ha), and the social indicators are labor use (h/ha) and annual work units (AWU).

\subsection{Area of Study}

The region of Central Macedonia is one of the 13 Greek regions (Figure 1). With regard to GDP and population, it is ranked second, and the total value of the primary sector is the highest in Greece [48]. According to the Hellenic Statistical Authority, the primary sector of the region corresponds to $22.6 \%$ of the total value of production in the country. The region includes seven prefectures with different crop plans (Imathia, Thessaloniki, Kilkis, Pella, Pieria, Serres, and Chalkidiki).

Wheat (hard and soft) is the main crop cultivated in the region in the nonirrigated and mountainous areas. Cotton is also a crop with great economic importance for the region, especially in Serres, Imathia, and Pella prefectures. Rice production is also an important for the prefectures of Thessaloniki and Serres. The crop plan of the region of Central Macedonia is presented in Table 2 [49]. In the crop plan are not included crops with cultivated area less than 10,000 ha and permanent crops, such as trees. 


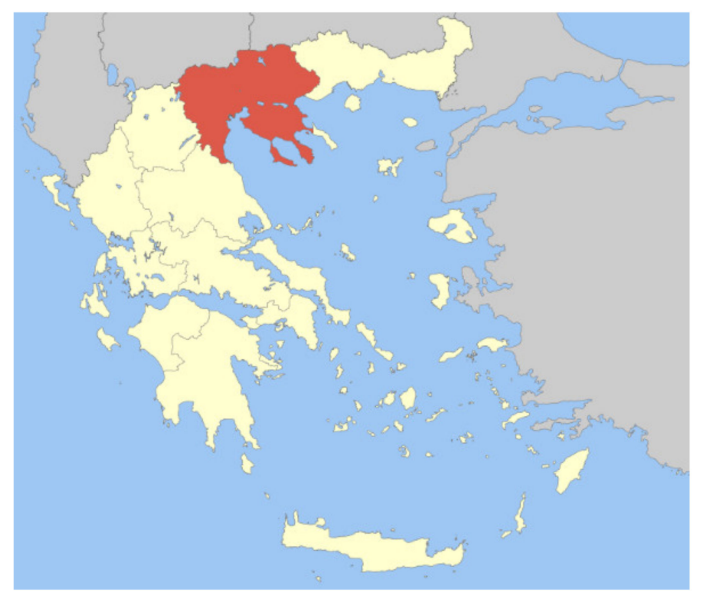

Figure 1. Map of the region of Central Macedonia in Greece.

Table 2. Crop plan of the region of Central Macedonia for 2018 [49].

\begin{tabular}{cccc}
\hline Crop & $\begin{array}{c}\text { Irrigated (I) } \\
\text { Non Irrigated (N) }\end{array}$ & $\begin{array}{c}\text { Area } \\
\text { (ha) }\end{array}$ & $\begin{array}{c}\text { Percentage } \\
\text { \% }\end{array}$ \\
\hline Rice & I & 24,279 & 5.45 \\
Hard Wheat & N & 101,718 & 22.83 \\
Sunflower & I & 23,452 & 5.26 \\
Soft Wheat & N & 45,220 & 10.15 \\
Maize & I & 29,596 & 6.64 \\
Barley & N & 31,634 & 7.10 \\
Cotton & I & 76,330 & 17.13 \\
Alfalfa & I & 43,963 & 9.87 \\
Set Aside (SA) & & 69,355 & 15.57 \\
Total & & 445,547 & 100 \\
\hline
\end{tabular}

The distribution of each crop in the crop plan of the region of Central Macedonia is presented in Figure 2. This distribution of crops is used as the crop plan of the average farm in the region. This is the base for all the calculations and results for the crop plans in this study, and it is assumed to be 100 ha.

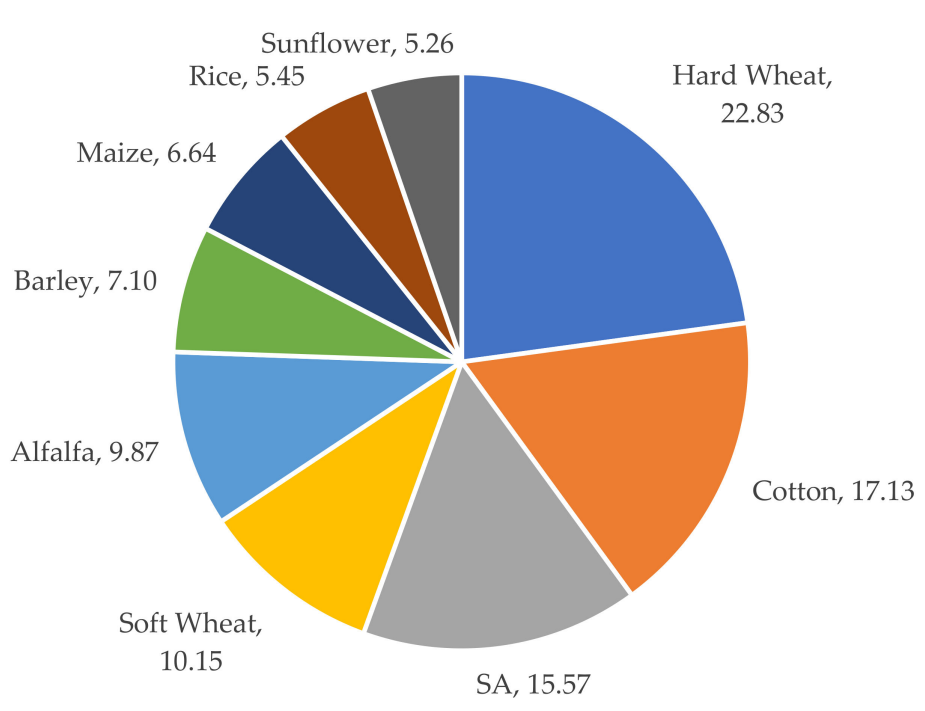

Figure 2. Distribution (\%) of the main crops of the region of Central Macedonia (2018) [48]. 


\section{Results}

\subsection{Multicriteria Model Results}

The implementation of the MCDM model, as described in the Methodology section, gave the following results with regard to the crop plan of the region of Central Macedonia in Greece. In Table 3, the payoff matrix of the MCDM model is presented. The results were obtained by solving the linear programming model for each one of the three objectives gross margin (GM max), fertilizers use (FER min), and total labor (TL min). The last column (actual 2018) shows the results of the existent crop plan in 2018. This matrix is used for the calculation of the weights of the farmers preferences with the use of the equations described in the Methodology section.

Table 3. Pay-off matrix of the MCDM model.

\begin{tabular}{ccccc}
\hline \multirow{2}{*}{ Values } & \multicolumn{3}{c}{ Optimum } & \multirow{2}{*}{ Actual } \\
\cline { 2 - 4 } & GM & FER & TL & $\mathbf{2 0 1 8}$ \\
\hline GM $(€)$ & 46,214 & 42,428 & 42,659 & 44,934 \\
FER $($ kg) & 39,757 & 38,693 & 40,121 & 40,458 \\
TL (hours) & 12,630 & 11,798 & 11,671 & 12,572 \\
\hline
\end{tabular}

The set of the weights for the actual 2018 situation is:

$$
\begin{aligned}
& w_{1}=0.64 \\
& w_{2}=0.00 \\
& w_{3}=0.36
\end{aligned}
$$

The final utility function will be:

$$
\mathrm{UF}=0.64 \mathrm{GM}-0.00 \mathrm{FER}-0.36 \mathrm{TL}
$$

The utility function shows that the most important criterion for farmers is the maximization of gross margin, and the second is the minimization of total labor.

The utility function, which was calculated before Equation (6), is then used as an objective function for the MCDM model. The optimum crop plan as percentage of the average farm area (100 ha) and the model values that were obtained are presented in Table 4.

Table 4. Optimum crop plan and MCDM model values for the year 2018.

\begin{tabular}{ccccc}
\hline Objectives & & $\begin{array}{c}\text { Actual } \\
\mathbf{2 0 1 8}\end{array}$ & $\begin{array}{c}\text { MCDM } \\
\mathbf{2 0 1 8}\end{array}$ & $\begin{array}{c}\text { Deviation } \\
\text { \% }\end{array}$ \\
\hline GM $(€)$ & 44,934 & 46,026 & 2.43 \\
\hline FER $(\mathrm{kg})$ & & 40,458 & 39,729 & -1.80 \\
\hline TL (hours) & Variables & $\begin{array}{c}\text { Area } \\
\text { \% }\end{array}$ & $\begin{array}{c}\text { Area } \\
\text { \% }\end{array}$ & $\begin{array}{c}\text { Deviation } \\
\text { \% }\end{array}$ \\
\hline Crops & $\mathrm{x}_{1}$ & 5.45 & 5.20 & -4.6 \\
\hline Rice & $\mathrm{x}_{2}$ & 22.83 & 20.02 & -12.3 \\
\hline Hard Wheat & $\mathrm{x}_{3}$ & 5.26 & 4.70 & -10.7 \\
\hline Sunflower & $\mathrm{x}_{4}$ & 10.15 & 11.70 & 15.3 \\
\hline Soft Wheat & $\mathrm{x}_{5}$ & 6.64 & 6.00 & -9.7 \\
\hline Maize & & & &
\end{tabular}


Table 4. Cont.

\begin{tabular}{|c|c|c|c|c|}
\hline Objectives & & $\begin{array}{c}\text { Actual } \\
2018\end{array}$ & $\begin{array}{c}\text { MCDM } \\
2018\end{array}$ & $\begin{array}{c}\text { Deviation } \\
\%\end{array}$ \\
\hline Barley & $\mathrm{x}_{6}$ & 7.10 & 7.70 & 7.7 \\
\hline Cotton & $x_{7}$ & 17.13 & 16.57 & -3.3 \\
\hline Alfalfa & $\mathrm{x}_{8}$ & 9.87 & 11.70 & 18.6 \\
\hline Set Aside & $x_{9}$ & 15.57 & 16.40 & 5.4 \\
\hline Total & & 100.0 & 100.0 & \\
\hline
\end{tabular}

The results show that the model managed to achieve all the three objectives that were set. The model achieved an increase of $2.43 \%$ for the gross margin while it achieved a decrease of $-1.81 \%$ in fertilizers use and $-0.01 \%$ in total labor.

The optimum crop plan includes all the crops that were present in the existent crop plan. All the cultivations and set aside present changes in the optimum crop plan. Alfalfa has the highest change by $18.6 \%$, while hard wheat has the highest decrease by $-12.3 \%$. Soft wheat, barley, and set aside change by $15.3 \%, 7.7 \%$, and $5.4 \%$, respectively. On the other hand, all the other crops are proposed to decrease (sunflower by $-10.7 \%$, maize by $-9.7 \%$, rice by $-4.6 \%$, and cotton by $-3.3 \%$ ). Figure 3 shows the changes in the optimum crop plan in comparison with the existent situation in 2018.

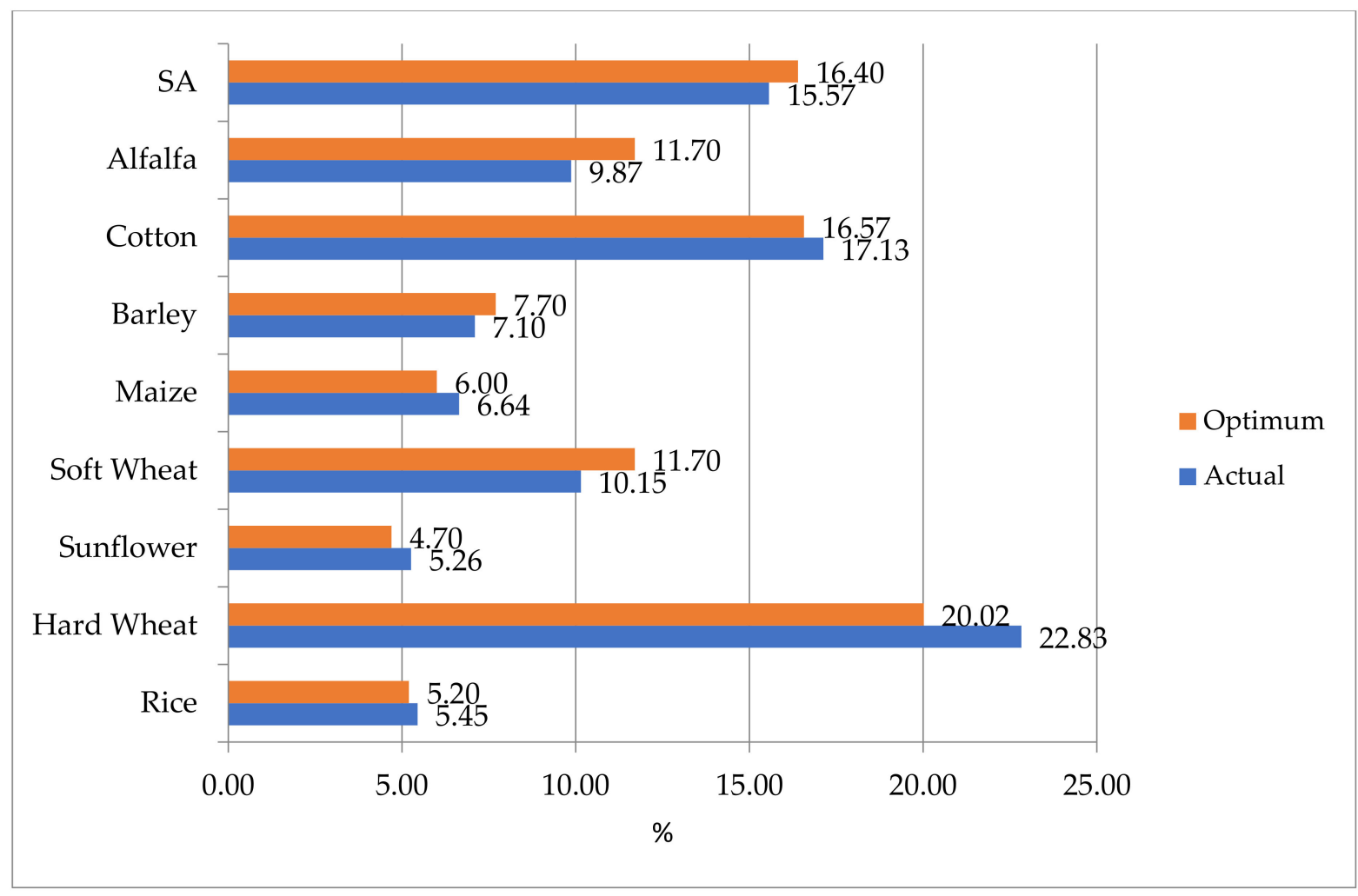

Figure 3. Actual crop plan vs. optimum crop plan (\%).

\subsection{Scenario Analysis Results}

The scenario analysis included three different scenarios, as mentioned in the Methodology section. The scenarios are the baseline 2018 scenario, scenario I 2025, and scenario II 2030. The model solved for each scenario and three new optimum crop plans were resulted. The crop plans represent the distribution of crops in the average farm (100 ha) of the region. 
Actual crop plan (2018) versus optimum crop plans for baseline (2018) scenario, scenario I (2025), and scenario II (2030) are presented in Table 5.

Table 5. Actual crop plan vs. optimum crop plans for baseline (2018) scenario, scenario I (2025), and scenario II (2030) (\%).

\begin{tabular}{|c|c|c|c|c|c|c|c|}
\hline Crops & $\begin{array}{l}\text { Actual (2018) } \\
\% \text { of ha }\end{array}$ & $\begin{array}{c}\text { Baseline (2018) } \\
\text { \% of ha }\end{array}$ & $\begin{array}{c}\text { Deviation } \\
\%\end{array}$ & $\begin{array}{c}\text { Scenario I } \\
\text { (2025) \% of ha }\end{array}$ & $\begin{array}{c}\text { Deviation } \\
\%\end{array}$ & $\begin{array}{c}\text { Scenario II } \\
(\mathbf{2 0 3 0 )} \% \text { of ha }\end{array}$ & $\begin{array}{c}\text { Deviation } \\
\%\end{array}$ \\
\hline Rice & 5.45 & 5.20 & -4.57 & 5.20 & -4.57 & 4.50 & -17.42 \\
\hline Hard Wheat & 22.83 & 20.02 & -12.31 & 19.79 & -13.32 & 19.79 & -13.32 \\
\hline Sunflower & 5.26 & 4.70 & -10.71 & 8.49 & 61.30 & 12.09 & 129.69 \\
\hline Soft Wheat & 10.15 & 11.70 & 15.28 & 11.70 & 15.28 & 11.70 & 15.28 \\
\hline Maize & 6.64 & 6.00 & -9.67 & 6.00 & -9.67 & 5.50 & -17.20 \\
\hline Barley & 7.10 & 7.70 & 8.45 & 7.70 & 8.45 & 7.70 & 8.45 \\
\hline Cotton & 17.13 & 16.57 & -3.28 & 15.40 & -10.11 & 14.00 & -18.28 \\
\hline Alfalfa & 9.87 & 11.70 & 18.57 & 9.31 & -5.65 & 8.31 & -15.78 \\
\hline Set Aside & 15.57 & 16.40 & 5.36 & 16.40 & 5.36 & 16.40 & 5.36 \\
\hline Total & 100 & 100 & & 100 & & 100 & \\
\hline
\end{tabular}

The baseline scenario crop plan was analyzed in the previous section. The scenario I 2025 crop plan has two main differences from the baseline 2018 crop plan. With regard to the nonirrigated crops, the only change is the decrease of the hard wheat from $20.02 \%$ to $19.79 \%$, as all the other nonirrigated crops (soft wheat, barley) remain stable in all scenarios. In the irrigated crops, there are several changes. Cotton and alfalfa decrease from $17.13 \%$ to $15.40 \%$ and from $9.87 \%$ to $9.31 \%$, respectively. On the other hand, the sunflower increases to $8.49 \%$ and maize remains stable. These changes are expected due to the reduction of the fertilizers and water use. The new crop plan has an increase in a crop that does not have high water and fertilizers needs, and similar reduction in cultivations (alfalfa and cotton) that are water- and fertilizers-intensive. The same changes continue into scenario II 2030 due to the same reasons. All the nonirrigated crops have the same changes as scenario I. This means that the changes in nonirrigated crops are stabilized and are not affected by the new climate change parameters. On the contrary, irrigated crops with high water needs continue to decrease in scenario II. Cotton, from $-10.11 \%$ deviation in scenario I, decreases in scenario II to $-18.28 \%$. Alfalfa, from $-5.65 \%$ deviation in scenario I, in scenario II presents $-15.78 \%$ deviation, and finally maize, which was stable in scenario I from the baseline scenario, decreases in scenario II to $-17.20 \%$. The sunflower, which is a crop with low water and fertilizers needs, increases to $12.09 \%$ from $5.26 \%$, a $129.69 \%$ deviation. We can summarize that the reduction in fertilizers and water use due to climate change implies low water and low fertilizer consumption for crops, and as fertilizers and water use decreases, irrigated crops are replaced by nonirrigated crops or less-irrigated crops.

The new suggested crop plans for the three scenarios have an impact on the selected economic and social indicators (Table 6). The baseline scenario with no change to parameters returned better economic results from the actual 2018 situation. The farm income, as family farm income, increases to $2.72 \%$, and as gross added value, increases to $2.23 \%$. An increase also represents the gross revenue by $0.31 \%$ and the gross margin by $2.43 \%$. The impact of the climate change as a response to the new crop plan and to the reduction of the water and fertilizers use has the opposite results to the selected economic indicators. In scenario I, a decrease is observed in farm income $(-4.96 \%)$ as family farm income and $-4.08 \%$ as gross added value, and $-4.43 \%$ in gross margin. A higher decrease is observed in gross revenues $(-5.09 \%)$ and in variable cost $(-5.48 \%)$.

The negative impacts of climate change in the economic indicators are obvious in scenario II. The farm income has reduction both as family farm income $(-10.65 \%)$ and as gross added value $(-8.74 \%)$. In addition, gross revenue has a decrease by $-10.49 \%$, variable cost by -11.07 , and gross margin by $-9.50 \%$. The negative economic impacts due 
to climate change in the region of Central Macedonia seem to be at low levels (Figure 4). This is due to the existent crop plan of the region which has alternative crops that can replace the water- and fertilizer-intensive crops.

Table 6. Socioeconomic indicators vs. scenario analysis.

\begin{tabular}{|c|c|c|c|c|c|c|c|}
\hline Indicators & $\begin{array}{l}\text { Actual } \\
(2018)\end{array}$ & Baseline 2018 & $\%$ & $\begin{array}{c}\text { Scenario I } \\
(2025)\end{array}$ & $\%$ & $\begin{array}{l}\text { Scenario II } \\
(2030)\end{array}$ & $\%$ \\
\hline $\begin{array}{c}\text { Farm Income } \\
\text { (Family Farm Income) }(€)\end{array}$ & 22,467 & 23,078 & $2.72 \%$ & 21,352 & $-4.96 \%$ & 20,075 & $-10.65 \%$ \\
\hline $\begin{array}{c}\text { Farm Income } \\
\text { (Gross Added Value) }(€)\end{array}$ & 19,444 & 19,878 & $2.23 \%$ & 18,651 & $-4.08 \%$ & 17,744 & $-8.74 \%$ \\
\hline Gross Revenue (€/ha) & 1221 & 1225 & $0.31 \%$ & 1159 & $-5.09 \%$ & 1093 & $-10.49 \%$ \\
\hline Variable Cost (€/ha) & 772 & 765 & $-0.92 \%$ & 730 & $-5.48 \%$ & 687 & $-11.07 \%$ \\
\hline Gross Margin (€/ha) & 449 & 460 & $2.43 \%$ & 429 & $-4.43 \%$ & 407 & $-9.50 \%$ \\
\hline Labor Use (h/ha) & 126 & 126 & $-0.01 \%$ & 119 & $-5.56 \%$ & 111 & $-11.71 \%$ \\
\hline Annual Work Unit (AWU) & 1.97 & 1.97 & $-0.01 \%$ & 1.87 & $-4.90 \%$ & 1.77 & $-10.31 \%$ \\
\hline
\end{tabular}

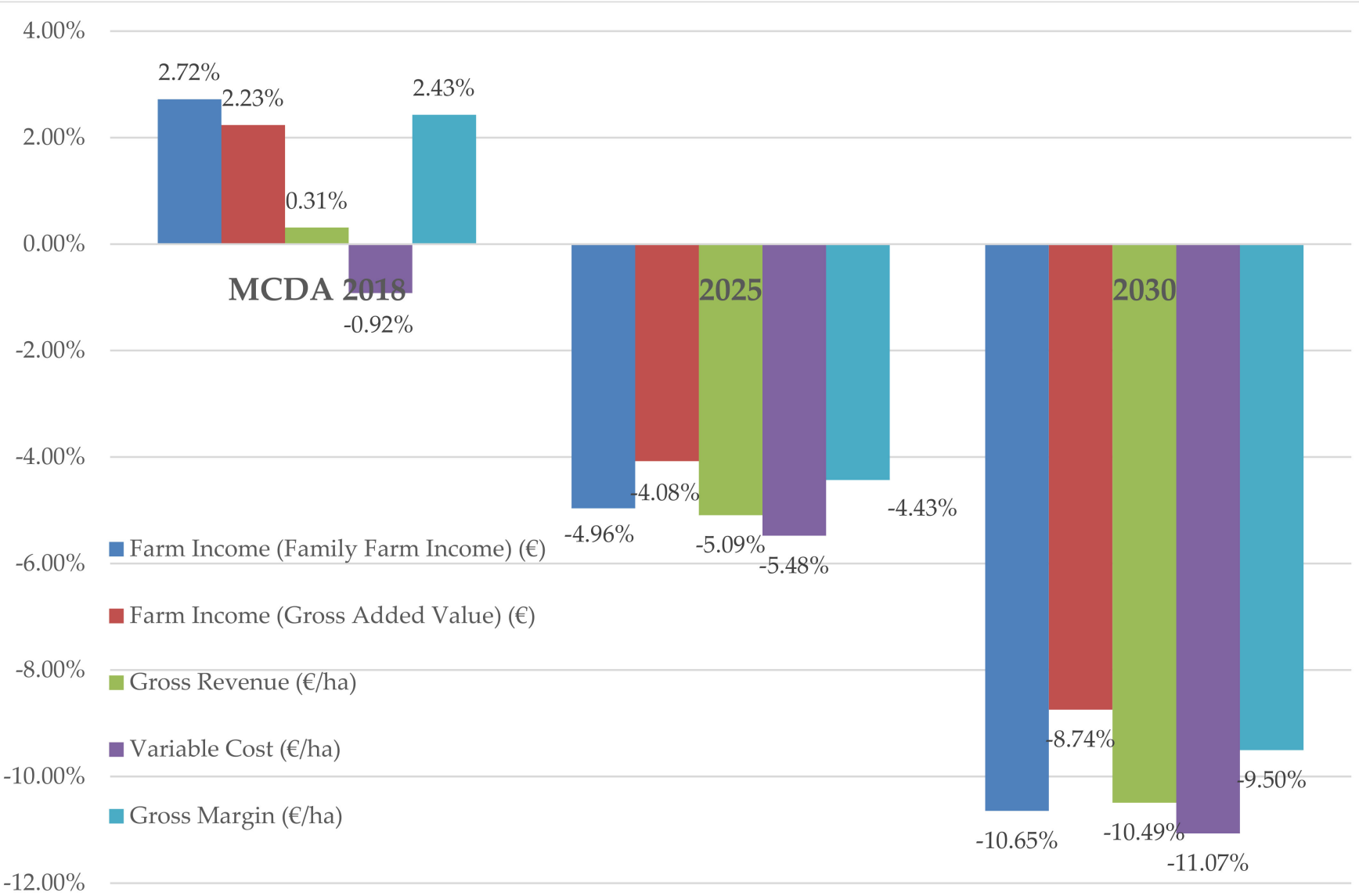

Figure 4. Economic indicators change.

The results of the social indicators are presented in Figure 5 With regard to the labor use, it presents a very low decrease in baseline $2018(-0.01 \%)$ and a higher decrease both in scenario I ( $-5.56 \%)$ and in scenario II (-11.71\%). The annual work unit indicator presents the same trends as labor use, as it is dependent on it. It has a small decrease in baseline 2018 scenario $(-0.01 \%)$ and a higher decrease in scenario I $(-4.90 \%)$ and in scenario II $(-10.31 \%)$.

The climate change impact, as expressed with a fertilizer use and water use reduction, brings about a severe reduction in farm labor inputs both in the short term and in the long term by reducing water and fertilizers use through changes in crop plans. In the proposed crop plans, the fertilizer-intensive or water-intensive crops are substituted with low-input 
crops and agricultural practices. This implies that nonirrigated crops and more mechanized crops will replace water-intensive crops, which will result in a continuous reduction of labor use.

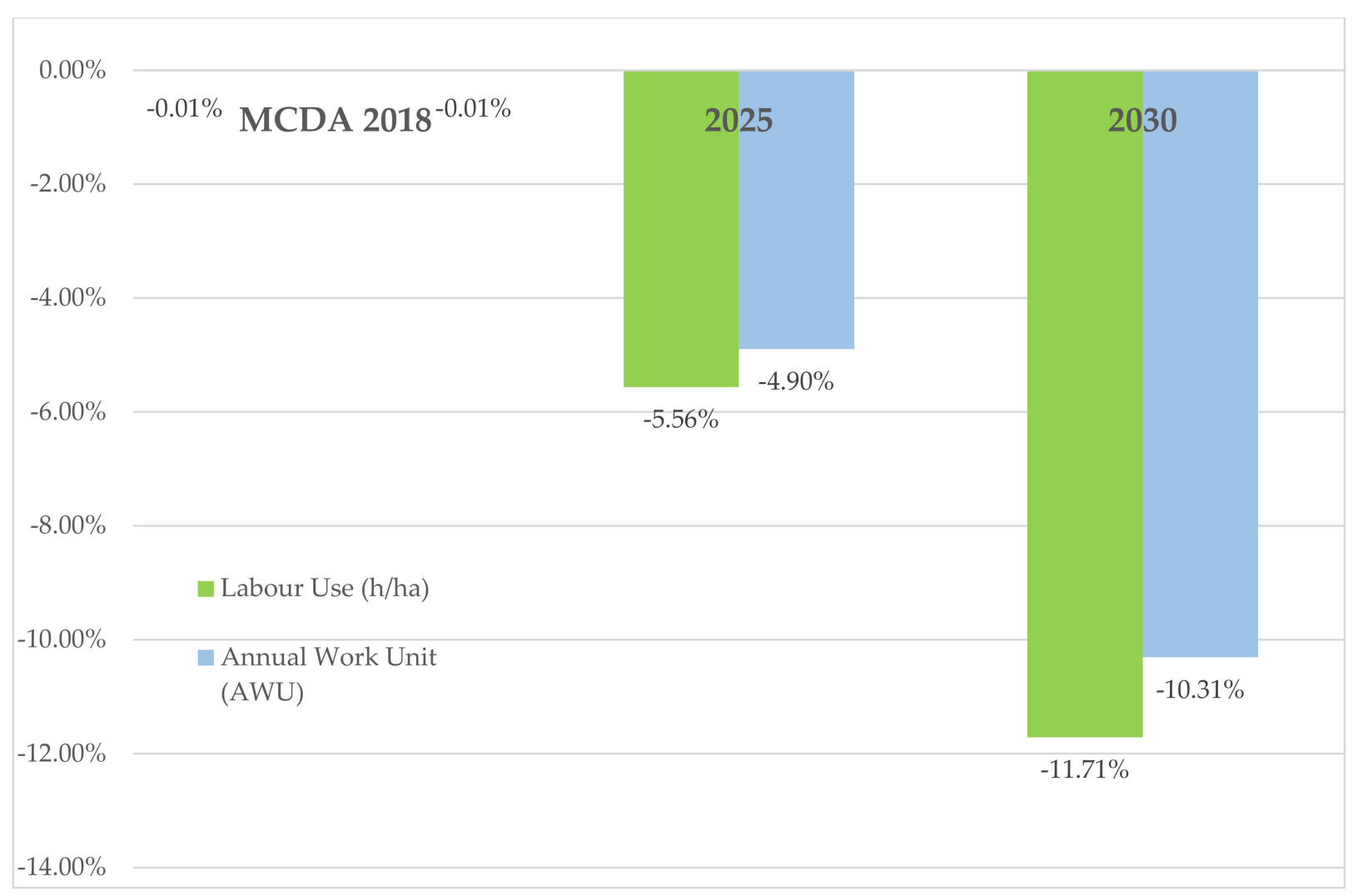

Figure 5. Social indicators change.

Other studies in the region of Central Macedonia present similar trends in the cultivated area changes and in the economic and social impacts of climate change. Georgopoulou et al. [50], in their study, estimated that there will be losses in the agricultural income between 2021-2050 because of climate change. In addition, as in our study, they argue that the water-intensive crops such as cotton and alfalfa are the principal reasons for "climate-winners" and for the limitation of the negative economic impacts. Another study of Giannakopoulos et al. [51] found that climate change will affect the length of the growing season and the number of frosty nights and days, especially in North Greece. These effects will impact the crop plans in the area, especially the sensitive crops such as fruit trees. These are similar results to our study, where cherry and peach trees agricultural areas are reduced in scenario I and scenario II.

\section{Conclusions}

In this paper, an attempt was made to assess the socioeconomic impacts of climate change in rural areas of Greece. For this reason, a multicriteria decision-making model was used in combination with a scenario analysis. We considered three objectives as the main goals of farmers' behavior: the maximization of gross margin, the minimization of fertilizers use, and the minimization of labor use. The scenario analysis included three scenarios derived from the study of representative concentration pathways (RCPs), the shared socioeconomic pathways, and data from the European Environment Agency for Greece. For that impact assessment, seven indicators, five economic and two social indicators, were measured.

With regard to the objectives, the results highlighted the maximization of gross margin as the main objective of farmers, and as a second objective, the minimization of labor. This 
was an expected result as the main crop plan of the region included intensive crops with high gross margin values and labor use, such as peach, cherry, and olive trees. The results also showed that climate change will have negative effects for the economic indicators as a response to the predicted reduction of fertilizers and water use. This reduction will modify the crop plans of farmers. The farmers will adopt crops that are less water- and fertilizers-intensive, and they will increase the cultivation of nonirrigated crops. Over the years, and with the continuing impact of climate change, the reduction of fertilizers use and water use will continue. In scenario II (2030), the negative economic impact of climate change increases.

With regard to the social impacts of climate change, the results showed that the labor use and annual work units will decrease as the nonirrigated crops are more mechanized crops and are less labor-intensive. The reduction will continue over the years, as described in the case of economic indicators. In Greek rural areas, where the relevance of agriculture in terms of employment is very important, the reduction of labor use may cause social problems. There are also many seasonal workers, especially immigrants, that will face low incomes and decreases in their working hours in the near future.

Focusing on the aims of this research, climate change is expected to have negative impact on social and economic indicators of rural areas. Therefore, policymakers should consider in their future policies the possible modifications in the crop plans of these areas due to climate change impacts. Agricultural policies should include measures for the improvement of agricultural practices and the adoption of new technologies considering the particular characteristic of the region.

In conclusion, the agricultural land-use change due to the climate change will reshape the agricultural potentials of the region of Central Macedonia. The farmers will adopt crops that are resistant to the new conditions and to the water and nitrates reduction. These crops will mainly replace the intensive tree cultivations that require labor, capital, and nitrates use. The final impact of these changes will be the reduction of farm income and the reduction of working hours, with negative economic and social impacts in the rural areas.

This research can be easily extended with a set of other social and economic indicators and with a set of environmental ones. Climate change impacts with multicriteria decision models in combination with scenario analysis constitutes an interesting and important horizon for future research. In addition, the adoption of the proposed shared socioeconomic pathways will also extend this research.

Author Contributions: Conceptualization, I.G. and C.M.; methodology, T.B.; software, I.G.; validation, T.B.; formal analysis, I.G.; data curation, I.G.; writing-original draft preparation, I.G.; writing-review and editing, T.B. and G.V.; supervision, B.M.; project administration, T.B.; funding acquisition, T.B. All authors have read and agreed to the published version of the manuscript.

Funding: This research is co-financed by Greece and the European Union (European Social FundESF) through the Operational Programme «Human Resources Development, Education and Lifelong Learning 2014-2020» in the context of the project "Adaptation of agricultural crops and ecosystem services to agricultural policy changes and climate change: An Integrated Impact Assessment of crops in Central Macedonia" (MIS 5047893).

Data Availability Statement: Not applicable.

Conflicts of Interest: The authors declare no conflict of interest.

\section{References}

1. Pretty, J.N.; Brett, C.; Gee, D.; Hine, R.E.; Mason, C.F.; Morison, J.I.L.; Raven, H.; Rayment, M.D.; van der Bijl, G. An assessment of the total external costs of UK agriculture. Agric. Syst. 2000, 65, 113-136. [CrossRef]

2. Hediger, W.; Lehmann, B. Multifunctional agriculture and the preservation of environmental benefits. Swiss J. Econ. Stat. 2007, 143, 449-470. [CrossRef]

3. Kampas, A.; White, B. Administrative costs and instrument choice for stochastic non-point source pollutants. Environ. Resour. Econ. 2004, 27, 109-133. [CrossRef] 
4. Lobell, D.B.; Burke, M.B.; Tebaldi, C.; Mastrandrea, M.D.; Falcon, W.P.; Naylor, R.L. Prioritizing climate change adaptation needs for food security in 2030. Science 2008, 319, 607-610. [CrossRef] [PubMed]

5. Van Ittersum, M.K.; Ewert, F.; Heckelei, T.; Wery, J.; Olsson, J.A.; Andersen, E.; Bezlepkina, I.; Brouwer, F.; Donatelli, M.; Flichman, G.; et al. Integrated assessment of agricultural systems-A component-based framework for the European Union (SEAMLESS). Agric. Syst. 2008, 96, 150-165. [CrossRef]

6. Schneider, U.A.; Havlík, P.; Schmid, E.; Valin, H.; Mosnier, A.; Obersteiner, M.; Böttcher, H.; Skalský, R.; Balkovič, J.; Sauer, T.; et al. Impacts of population growth, economic development, and technical change on global food production and consumption. Agric. Syst. 2011, 104, 204-215. [CrossRef]

7. Ray, D.K.; Mueller, N.D.; West, P.; Foley, J.A. Yield trends are insufficient to double global crop production by 2050. PLoS ONE 2013, 8, e66428. [CrossRef]

8. Easterling, W.E. Climate change and the adequacy of food and timber in the 21st century. Proc. Natl. Acad. Sci. USA 2007, 104, 19679. [CrossRef]

9. Reidsma, P.; Ewert, F.; Lansink, A.O.; Leemans, R. Adaptation to climate change and climate variability in European agriculture: The importance of farm level responses. Eur. J. Agron. 2010, 32, 91-102. [CrossRef]

10. Kanellopoulos, A.; Reidsma, P.; Wolf, J.; van Ittersum, M. Assessing climate change and associated socio-economic scenarios for arable farming in the Netherlands: An application of benchmarking and bio-economic farm modelling. Eur. J. Agron. 2014, 52, 69-80. [CrossRef]

11. Parry, M.L.; Rosenzweig, C.; Iglesias, A.; Livermore, M.; Fischer, G. Effects of climate change on global food production under SRES emissions and socio-economic scenarios. Glob. Environ. Chang. 2004, 14, 53-67. [CrossRef]

12. Jones, P.G.; Thornton, P.K. The potential impacts of climate change on maize production in Africa and Latin America in 2055. Glob. Environ. Chang. 2003, 13, 51-59. [CrossRef]

13. Von Cossel, M.; Wagner, M.; Lask, J.; Magenau, E.; Bauerle, A.; von Cossel, V.; Warrach-Sagi, K.; Elbersen, B.; Staritsky, I.; van Eupen, M.; et al. Prospects of bioenergy cropping systems for a more social-ecologically sound bioeconomy. Agronomy 2019, 9, 605. [CrossRef]

14. Abildtrup, J.; Audsley, E.; Fekete-Farkas, M.; Giupponi, C.; Gylling, M.; Rosato, P.; Rounsevell, M. Socio-economic scenario development for the assessment of climate change impacts on agricultural land use: A pairwise comparison approach. Environ. Sci. Policy 2006, 9, 101-115. [CrossRef]

15. Nelson, R.; Kokic, P.; Crimp, S.; Meinke, H.; Howden, S.M. The vulnerability of Australian rural communities to climate var-iability and change: Part I-Conceptualising and measuring vulnerability. Environ. Sci. Policy 2010, 13, 8-17. [CrossRef]

16. Stefanova, A.; Hesse, C.; Krysanova, V.; Volk, M. Assessment of socio-economic and climate change impacts on water re-sources in Four European Lagoon Catchments. Environ. Manag. 2019, 64, 701-720. [CrossRef]

17. Martínez-Gomariz, E.; Locatelli, L.; Guerrero, M.; Russo, B.; Martínez, M. Socio-economic potential impacts due to urban pluvial floods in Badalona (Spain) in a context of climate change. Water 2019, 11, 2658. [CrossRef]

18. Locatelli, L.; Guerrero, M.; Russo, B.; Martínez-Gomariz, E.; Sunyer, D.; Martínez, M. Socio-economic assessment of green infrastructure for climate change adaptation in the context of urban drainage planning. Sustainability 2020, 12, 3792. [CrossRef]

19. Ougougdal, H.A.; Khebiza, M.Y.; Messouli, M.; Lachir, A.; Ougougdal, H.A. Assessment of future water demand and supply under IPCC climate change and socio-economic scenarios, using a combination of models in Ourika Watershed, High Atlas, Morocco. Water 2020, 12, 1751. [CrossRef]

20. Ardakani, Z.; Bartolini, F.; Brunori, G. Economic modeling of climate-smart agriculture in Iran. New Medit. 2019, 2019, 29-40.

21. Vollaro, M.; Zavalloni, M.; Raggi, M.; Viaggi, D. Adapting to climate change: The social perception of voluntary water transfers in the Italian context. Int. J. Sustain. Agric. Manag. Inform. 2015, 1, 26. [CrossRef]

22. Lal, P.; Alavalapati, J.R.R.; Mercer, E.D. Socio-economic impacts of climate change on rural United States. Mitig. Adapt. Strat. Glob. Chang. 2011, 16, 819-844. [CrossRef]

23. Gomes, T.M.R.C. The European Union accession and climate change policies in the western Balkan countries. In Contributions to Economics; Sequeira, T., Reis, L., Eds.; Springer Science and Business Media LLC: Berlin/Heidelberg, Germany, 2019 ; pp. 153-173.

24. Salvia, R.; Egidi, G.; Vinci, S.; Salvati, L. Desertification risk and rural development in southern Europe: Permanent assessment and implications for sustainable land management and mitigation policies. Land 2019, 8, 191. [CrossRef]

25. Nastis, S.; Michailidis, A.; Chatzitheodoridis, F. Climate change and agricultural productivity. Afr. J. Agric. Res. 2012, 35, 4885-4893. [CrossRef]

26. Organisation for Economic Co-operation and Development (OECD). Regional Policy for Greece Post-2020; OECD Territorial Reviews; OECD Publishing: Paris, France, 2020.

27. Eurostat Region of Kentriki Makedonia—Internal Market, Industry, Entrepreneurship and Smes—European Commission. Available online: https: / /ec.europa.eu/growth/tools-databases/regional-innovation-monitor/base-profile/region-kentrikimakedonia (accessed on 27 April 2021).

28. Recchia, L.; Boncinelli, P.; Cini, E.; Vieri, M.; Pegna, F.G.; Sarri, D. General theory of multicriteria analysis and life cycle assessment. SSPCR 2011, 91, 5-26.

29. Sumpsi, J.M.; Amador, F.; Romero, C. A Research on the Andalusian Farmers' Objectives: Methodological Aspects and Policy Implications; European Association of Agricultural Economists (EAAE): Wageningen, The Netherlands, 1993.

30. Sumpsi, J.; Amador, F.; Romero, C. On farmers' objectives: A multi-criteria approach. Eur. J. Oper. Res. 1997, 96, 64-71. [CrossRef] 
31. Amador, F.; Sumpsi, J.M.; Romero, C. A non-interactive methodology to assess farmers' utility functions: An application to large farms in Andalusia, Spain. Eur. Rev. Agric. Econ. 1998, 25, 92-102. [CrossRef]

32. Berbel, J.; Rodriguez-Ocaña, A. An MCDM approach to production analysis: An application to irrigated farms in Southern Spain. Eur. J. Oper. Res. 1998, 107, 108-118. [CrossRef]

33. Gómez-Limón, J.A.; Arriaza, M.; Berbel, J. Conflicting implementation of agricultural and water policies in irrigated areas in the EU. J. Agric. Econ. 2002, 53, 259-281. [CrossRef]

34. Arriaza, M.; Gómez-Limón, J.A.; Upton, M. Local water markets for irrigation in southern Spain: A multicriteria approach. Aust. J. Agric. Resour. Econ. 2002, 46, 21-43. [CrossRef]

35. Manos, B.; Bournaris, T.; Kamruzzaman, M.; Begum, M.; Anjuman, A.; Papathanasiou, J. Regional impact of irrigation water pricing in Greece under alternative scenarios of European policy: A multicriteria analysis. Reg. Stud. 2006, 40, 1055-1068. [CrossRef]

36. Bournaris, T.; Moulogianni, C.; Manos, B. A multicriteria model for the assessment of rural development plans in Greece. Land Use Policy 2014, 38, 1-8. [CrossRef]

37. Bournaris, T.; Moulogianni, C.; Arampatzis, S.; Kiomourtzi, F.; Wascher, D.; Manos, B. A knowledge brokerage approach for assessing the impacts of the setting up young farmers policy measure in Greece. Environ. Impact Assess. Rev. 2016, 57, 159-166. [CrossRef]

38. Bartolini, F.; Gallerani, V.; Raggi, M.; Viaggi, D. Water management and irrigated agriculture in Italy: Multicriteria analysis of alternative policy scenarios. Hydrol. Res. 2009, 12, 135-147. [CrossRef]

39. Gómez-Limón, J.A.; Berbel, J. Multicriteria analysis of derived water demand functions: A Spanish case study. Agric. Syst. 2000, 63, 49-72. [CrossRef]

40. Romero, C. Handbook of Critical Issues in Goal Programming; Elsevier: Amsterdam, The Netherlands, 1991.

41. Van Vuuren, D.P.; Edmonds, J.; Kainuma, M.; Riahi, K.; Thomson, A.; Hibbard, K.; Hurtt, G.C.; Kram, T.; Krey, V.; Lamarque, J.-F.; et al. The representative concentration pathways: An overview. Clim. Chang. 2011, 109, 5-31. [CrossRef]

42. Riahi, K.; van Vuuren, D.P.; Kriegler, E.; Edmonds, J.; O’Neill, B.C.; Fujimori, S.; Bauer, N.; Calvin, K.; Dellink, R.; Fricko, O.; et al. The shared socioeconomic pathways and their energy, land use, and greenhouse gas emissions implications: An overview. Glob. Environ. Chang. 2017, 42, 153-168. [CrossRef]

43. Kok, K.; Pedde, S.; Gramberger, M.; Harrison, P.A.; Holman, I. New European socio-economic scenarios for climate change research: Operationalising concepts to extend the shared socio-economic pathways. Reg. Environ. Chang. 2018, 19, 643-654. [CrossRef]

44. Kriegler, E.; O’Neill, B.C.; Hallegatte, S.; Kram, T.; Lempert, R.J.; Moss, R.H.; Wilbanks, T. The need for and use of socio-economic scenarios for climate change analysis: A new approach based on shared socio-economic pathways. Glob. Environ. Chang. 2012, 22, 807-822. [CrossRef]

45. European Environment Agency. Climate Change Pressure Indicators at Country and European Level for Short and Medium Term (1990-2030). Available online: https://www.eea.europa.eu/data-and-maps/figures/climate-change-scenarios-data (accessed on 20 May 2021).

46. Schermer, M.; Stotten, R.; Strasser, U.; Meißl, G.; Marke, T.; Förster, K.; Formayer, H. The role of transdisciplinary research for agricultural climate change adaptation strategies. Agronomy 2018, 8, 237. [CrossRef]

47. Parra, L.; Botella-Campos, M.; Puerto, H.; Roig-Merino, B.; Lloret, J. Evaluating irrigation efficiency with performance indi-cators: A case study of citrus in the east of Spain. Agronomy 2020, 10, 1359. [CrossRef]

48. Ragkos, A.; Samathrakis, V.; Theodoridis, A.; Notta, O.; Batzios, C.; Tsourapas, E. Specialization and concentration of agri-cultural production in the region of central Macedonia (Greece). In Proceedings of the 7th International Conference on Information and Communication Technologies in Agriculture, Food and Environment, Kavala, Greece, 17-20 September 2015; Volume 1498, pp. 304-319.

49. Hellenic Statistical Authority. Agricultural Areas and Production. Available online: https://www.statistics.gr/en/statistics/-/ publication/SPG06/- (accessed on 28 March 2021).

50. Georgopoulou, E.; Mirasgedis, S.; Sarafidis, Y.; Vitaliotou, M.; Lalas, D.; Theloudis, I.; Giannoulaki, K.-D.; Dimopoulos, D.; Zavras, V. Climate change impacts and adaptation options for the Greek agriculture in 2021-2050: A monetary assessment. Clim. Risk Manag. 2017, 16, 164-182. [CrossRef]

51. Giannakopoulos, C.; Kostopoulou, E.; Varotsos, K.V.; Tziotziou, K.; Plitharas, A. An integrated assessment of climate change impacts for Greece in the near future. Reg. Environ. Chang. 2011, 11, 829-843. [CrossRef] 